\title{
Agriculture teachers' importance and competency levels in developing students' entrepreneurial competencies in Eswatini
}

\author{
Zanele M. Gule* $\bullet$ Comfort B. S. Mndebele
}

Department of Agricultural Education and Extension, Faculty of Agriculture, University of Eswatini, Eswatini, Swaziland.

${ }^{*}$ Corresponding author. E-mail: gulem@uniswa.sz. Tel: +268 76996612.

Accepted $3^{\text {rd }}$ January, 2019.

\begin{abstract}
The main aim of the study was to determine the importance and competence levels of high school agriculture teachers to impart entrepreneurship skills to learners in the Kingdom of Eswatini. The study was a descriptive survey conducted in two phases. Phase I (semi-structured interviews) identified twenty (20) entrepreneurial skills used for Phase II (survey). A census study of all 290 agriculture teachers (modern and pre-vocational) was conducted. Questionnaire was used to collect data from 227 agriculture teachers. Cronbach alpha was used to establish the internal consistency of the questionnaire to be 0.89 . Content and face validity was established by a panel of experts. Data collected was analyzed using means and standard deviations, whilst Borich's Model was used to identify entrepreneurial skills that agriculture teachers needed for in-service training. Findings revealed all 20 identified entrepreneurial skills as important; however, teachers indicated competence in six entrepreneurial skills and incompetence in 14 entrepreneurial skills which were ranked by the Borich's model as training need areas. It was concluded that agriculture teachers were not adequately trained in the entrepreneurial skills; therefore a need for in-service training in the 14 identified entrepreneurial skills. It was recommended that the institution for agriculture teachers pre-service training review the curriculum in entrepreneurship to focus more on building competency of teachers in the entrepreneurial skills training need areas; and agriculture teachers should be given opportunities and support needed to participate in capacity building workshops.
\end{abstract}

Keywords: Entrepreneurship, entrepreneurial skill, agriculture teacher competence, in-service training needs, entrepreneurship education.

\section{INTRODUCTION}

Entrepreneurship has been an issue examined by many theorists due to its positive contributions to economic and social life in each period of human history (Kapu, 2001). There seems to be wide spread recognition that it is the engine, driving the economy and society of most nations (Seikkula-Leino et al., 2012). Nowadays both scholars and policy makers are becoming aware of the importance of the educational system for entrepreneurship. There are two developed points of view in defining entrepreneurship. The first is from the school of economics and the second, from the education school. The school of economics defines entrepreneurship as the creation of value through the establishment of organizations. Entrepreneurs create value through exploration, innovation, thinking creatively and by finding new products, services, sources, technologies and markets. The second approach focuses on the individual and aims to improve the entrepreneurial attitudes and behaviors of the students (European Commission, 2004). This definition could be taken as education, empowerment, 
and or training of individuals lead to change in personality, orientation and attitudes which eventually lead to modified behavior. In this sense, the second approach in education is emphasized. So, it is seen that the development of students' creativity and innovation has gained importance in the training given in the field of education (Abiogu, 2011).

Most empirical studies conducted indicate that entrepreneurship can be taught and that education can foster entrepreneurship (Garcia-Rodriguez et al., 2017; Potishuk and Kratzer, 2017; Malach and Kristova, 2017; Zhang et al., 2014; Ahmad, 2007). This is evidenced by the growing number of entrepreneurship modules in higher education, the spread of such modules beyond pure business and economics disciplines, the sustained (and in some countries, increasing) number of entrepreneurship faculty at reader and professorial level, and the growing number of international conferences, books and calls for papers on the topic (Henry and McGowan, 2016) According to Bandura (1986), education can serve as a preparatory function in relation to new venture initiation or start - up, whereby the transfer of knowledge and acquisition and development of relevant skills would be expected to increase the selfefficacy and effectiveness of the potential entrepreneur (p.56). Entrepreneurship education is imperative as today young people are living in a market where unstable job, contract work and unemployment are the norm.

\section{Entrepreneurship education}

As a research area, entrepreneurship education has attracted increased scholarly attention in recent decades (Garcia-Rodriguez et al., 2017). Many nations are focusing on the entrepreneurial education on both primary and higher education level because it is considered that entrepreneurship minimize the unemployment problem and generate more income particularly in the developing nations (Malach and Kristova, 2017; Nabi et al., 2017; Potishuk and Kratzer, 2017; Ghina et al., 2017). Entrepreneurship education is defined as a process through which learners acquire a broad set of competencies and can bring greater individual, social and economic benefits (Ndedi, 2009). It refers to an individual's ability to turn ideas into action. It includes; 1) creativity, 2) innovation, 3) showing initiative, 4) risk-taking, and 5) the ability to plan and manage projects. This supports everyone in day-to-day life at home and in the society and makes employees more aware of the context of their work and better able to seize opportunities. Entrepreneurship education is thus about life-wide as well as lifelong competence development.

The entrepreneurial process has been described by Bygrave (2004) as a set of stages and events that follow one another. It begins with the idea generation, wherein the entrepreneur identifies and evaluates the business opportunities. Once the opportunity has been decided upon, the next step is to evaluate it. Once the opportunity is identified, an entrepreneur needs to create a comprehensive business plan. This is critical to the success of any new venture since it acts as a benchmark and the evaluation criteria to see if the organization is moving towards its set goals. The third step is resourcing, wherein the entrepreneur identifies the sources from where the finance and the human resource can be arranged. Here, the entrepreneur finds the investors for its new venture and the personnel to carry out the business activities. Once the funds are raised and the employees are hired, the next step is to initiate the business operations to achieve the set goals. The final step in the entrepreneurial process is harvesting wherein, an entrepreneur decides on the future prospects of the business, i.e. its growth and development. Here, the actual growth is compared against the planned growth and then the decision regarding the stability or the expansion of business operations is undertaken accordingly, by an entrepreneur. The entrepreneurial process is to be followed, again and again, whenever any new venture is taken up by an entrepreneur, therefore, it is an ever-ending process (Bygrave, 2004).

Enterprise education, therefore aims to produce graduates with the mindset and skills to come up with original ideas in response to identified needs and shortfalls, and the ability to act on them, in short, having an idea and making it happen (Simiyu, 2010). This education extends beyond knowledge acquisition to a wide range of emotional, intellectual, social, and practical skills. The most commonly cited goals of entrepreneurship education by previous studies are firstly, attainment of fundamental expertise, inculcating contemporary knowledge of science and technology, efficient communication, and problem solving. These skills are of paramount importance to excel professionally in suitable working environment. Secondly, to achieve excellence in social and individual level by inculcating merits like team work, efficient problem solving, being innovative and creative, the quality of taking risks, selfknowledge and self-esteem. Thirdly, for productive financial management and creation of successful enterprise, instilling skills like effective marketing, sales, human resource management, creating and building personal and business budgets and designing business plans (Papagiannis, 2018; OECD, 2009).

The Ministry of Education and Training Policy (2012) has specifically linked the development of entrepreneurial attitudes and behaviors to education and training. In addition, entrepreneurial knowledge, entrepreneurial intentions, capacity and skills, are developed by entrepreneurial education that are consistent with the requirements of the economy. Pham (2018) also argued that entrepreneurship is encouraged with the help of entrepreneurship education and that entrepreneurial activities are significantly influenced by entrepreneurship 
education and entrepreneurial education help out to develop potential entrepreneurial activities. Hence teachers have a critical role to play in the development and promotion of entrepreneurship education alongside other stakeholders such as regional/local authorities and the private and non-profit sector. Entrepreneurship education in schools and higher education institutions is promoted by national initiatives and strategies; curricula and schools and hence teachers are expected to develop knowledge, skills and attitudes in this area. In most countries, such as the Kingdom of Eswatini, political willingness to implement entrepreneurship education in schools at primary and secondary level has been identified. However, the quality of teaching has been the single most important within-school factor affecting student attainment (Ndwandwe, 2013). Hence, the need for increased support to teachers and educators in several key areas such as providing specific education to teachers in entrepreneurship and link this to the national curriculum reforms; adopting innovative methods to train teachers in entrepreneurship and setting-up incentives at school level to enable teachers to teach entrepreneurship.

\section{Entrepreneurial education in the Kingdom of Eswatini}

Due to the high rate of the educated unemployed, the Government of Eswatini introduced an element of entrepreneurship education to a child in Eswatini as early as Grade three and runs through to Grade seven. Children at this level are introduced to a subject known as Practical Arts. The idea is for the child to discover which field of practical art each child has and encourage the child to think beyond talent and skill and actually think of ways in which these could be used to make a profit (Ministry of Education and Training Policy, 2012).

At secondary level, there is the Prevocational and Entrepreneurship programme at Form 4 and Form 5, offered in about 16 schools in the country. The aim of this initiative was to provide education that works towards motivating and preparing pupils for self-employment opportunities while they are still at school and to change attitudes so that farming which means working on the land using one's own hands in skilled trades, was not regarded as an inferior way of existence and therefore rejected as a means of livelihood (Khumalo, 2010).

The aspect of entrepreneurship education was also introduced in the University of Eswatini - Luyengo and has helped to raise awareness among graduates about the demands of the employment sector. Entrepreneurship courses taken by all students at the University and are expected to equip students with needed knowledge, skills and attitudes. Students specifically are to develop business plan, prepare proposal for funding, run the proposed business, and market their services or products. In the academic year $2005 / 2006$, for example, academic departments in the Faculty of Agriculture examined their pertinent diploma/degree programmes, and identified overlaps in courses. This resulted in reduction of the duration of programmes from five to four years. This came with changes in courses offered to respond to the current socioeconomic challenges. There were a number of courses introduced and Entrepreneurship is among them (University Calendar, 2012/2013).

According to Haftendorn (2003), a generation without the hope of a stable job is a burden for the whole of society. Poor employment in the early stages of a young person's career can harm job prospects for life. Haftendon further states that, the economic investment of governments in education and training will be wasted if young people do not move into productive jobs that enable them to pay taxes and support public services. Hence, countries should try to explore ways to increase youth employment which will help end the vicious cycle of poverty and social exclusion. Self-employment and micro, small and medium enterprises are routes that young people can actively explore to forge their future and promote a positive enterprise culture is a way to facilitate youth employment. As a result, entrepreneurship has emerged as a viable livelihood option and is thus high on the policy agenda in Eswatini. The potential influence that agriculture teachers have on the delivery and implementation of business and entrepreneurial skills, training to the youth in schools into transforming them into entrepreneurs when they graduate cannot be overemphasized. These play a very important role in providing students with entrepreneurial characteristics (Akyürek and Şahin, 2013; Gardner, 2013; Hannula, 2011).

Layfield and Dobbins (2002) in a study to determine inservice needs and perceived competencies of South Carolina agricultural educators noted that "now, more than ever, teachers are among those for whom learning is a lifelong proposition (p.46)" and there have been ways to train and re-train teachers. However, to be successful in training teachers, correctly identifying their training needs is of the highest priority. Several studies have used Borich's (1980) needs assessment model to identify in-service needs of agriculture teachers (Layfield and Dobbins, 2002). Borich defined training need as a discrepancy between an educational goal and trainee performance in relation to this goal. The model employs two extreme positions: what are (measured behaviors, skills and competencies of trainees) and what should be (the goals of the training program). The Borich Needs Assessment Model is therefore, a credible tool in assessing needs of secondary agriculture educators (Layfield and Dobbins, 2002). As a result, this study also utilized the Borich's model to determine in-service training needs of agriculture teachers with regards to the entrepreneurial skills needed to transform learners into entrepreneurs. 


\section{Problem of the study}

According to Ndwandwe (2013), agriculture teachers in Eswatini have been found to be deficient in teaching entrepreneurial skills to learners. Therefore, the training received by the youth at school is not fully comprehended by teachers to equip them with the required skills and competencies needed for job creation and selfemployment. Secondary school leavers for whom there exist little or no job market skills are still produced by agriculture teachers in schools. Henry et al., (2005), on the other hand states that the success of the youth in the classroom learning process cannot be separated from the role and competency of the teacher. The quality of teacher competence plays an important role in the creation and establishment of the quality of the learning process for students, and can contribute in improving learning performance. Ensuring also, that teachers are involved in identifying the entrepreneurial skills may increase the likelihood of achieving appropriate outcomes (Waters and Haskel, 1989).

Most of the research studies in Eswatini, however, have not been able to involve teachers in identifying the important entrepreneurial skills as well as their competences to teach each skill. As a result, the youth is deficient in basic entrepreneurial and productive skills required to function effectively as entrepreneurs, hence the unemployment menace in the country (United Nations Report, Swaziland, 2013). This has created a knowledge gap that this research sought to contribute to fill. Consequently, there was need to identify the in-service training needs of agriculture teachers to impart appropriate and adequate entrepreneurship skills to high school learners, hence the use of the Borichs' model as expounded above.

\section{Purpose and objectives of the study}

The main purpose of the study was to identify importance and competency levels of high school agriculture teachers in developing student entrepreneurial competencies and suggest solutions for improving teacher training in Eswatini. The specific objectives were to:

1. Describe agriculture teachers' importance levels to impart entrepreneurship skills to high school learners.

2. Describe agriculture teachers' competence levels to impart entrepreneurship skills to high school learners.

3. Describe the relationship between competence levels of agriculture teachers and their background and demographic characteristics such as perceived ability to impart entrepreneurship, region of school, name of institution, sex, age, highest academic qualification, subjects taught, and teaching experience.

4. Identify in-service training needs of agriculture teachers to impart entrepreneurial skills to learners.

\section{Research hypothesis}

Null hypothesis: There is no significant relationship between teachers' competence levels and their perceived ability to impart entrepreneurial skills, gender, age, and educational level, region of school, subject taught and teaching experience of agriculture teacher.

\section{MATERIALS AND METHODS}

The target population for the study was agriculture teachers $(N=290)$. A Census study was conducted, therefore, all agriculture teachers, both Modern and Prevocational were included in the study.

Modern agriculture is taken by students under the academic stream which leads to Eswatini International general certificate of secondary education examination. It is geared toward self-employment, and provides the technical background which would enable the more able students to continue to higher education. The prevocational agriculture is taken by students under the prevocational stream which leads to a pre-vocational school leaving certificate issued by the Examination Council of Eswatini. It provides opportunities for those learners who cannot continue to higher education to be self-employed by motivating and preparing them for employment opportunities while they are still at school (Ministry of Education and Training Policy, 2012).

Semi structured interviews (Phase I) and a survey questionnaire (Phase II) were used to collect data. In Phase I of the study, ten (10) purposively-selected key informants possessing knowledge on entrepreneurship development in the different tertiary institutions in Eswatini were interviewed to identify the relevant entrepreneurial skills that need to be taught to high school learners by agriculture teachers. The identified entrepreneurial skills were twenty (20) and were further divided by experts into ten (10) entrepreneurship skills and ten (10) managerial skills. Both groups of skills became part of the survey instrument administered to agriculture teachers in Eswatini in Phase II of the study. A group of six (6) entrepreneurship experts from the Universities of Eswatini, Luyengo and Kwaluseni reviewed the questionnaire and attested to its face and content validity. A pilot study with agriculture teachers not participating in this study produced Cronbach's alpha internal consistency reliability coefficient of .89 .

The survey instrument was in two parts. Part I requested respondents to provide demographic characteristics deemed possibly influencing their ratings. Part II listed the twenty entrepreneurial skills. Respondents were requested to indicate their ratings on a one to six-point Likert-type scale. The importance scale was anchored as follows: $6=$ Extremely Important; $5=$ Important; $4=$ Slightly Important; $3=$ Slightly Unimportant; 2 = Unimportant and, 1 = Extremely Unimportant. To determine competence level of teachers 
to teach the entrepreneurship skills to learners in high school, respondents were asked to indicate their ratings on a one to six a Likert-type scale. The competence scale was anchored as follows: 6 = Extremely Competent, $5=$ Competent, $4=$ Slightly Competent, $3=$ Slightly Incompetent, 2 = Incompetent and, $1=$ Extremely Incompetent. Researcher was able to deliver and collect the completed instruments within a month. The response rate from agriculture teachers was $87 \%(n=227)$.

Computation of data using the Statistical Package for Social Sciences (SPSS v.20) generated descriptive and correlational statistics. Descriptive statistics such as means and standard deviations were used to describe the data. Study tried to establish if there was a relationship between teachers' competence levels, represented by $\mathrm{Y}$, and selected variables represented by $X$, which are; perceived ability to impart entrepreneurship, region, sex, age, highest academic qualification, subject taught and teaching experience. Correlations were used to determine if there is a relationship between the variables.

Pearson-product coefficient $(r)$ was used where both characteristics were measured at the interval or ratio scale. Point biserial $\left(\mathrm{r}_{\mathrm{pb}}\right)$ was used where one characteristic was continuous and the other was dichotomous (nominal data with natural split). Biserial was used when one characteristic was interval and the other was ordinal. Davis' (1971) correlation descriptors were used to describe the relationship between characteristics. The weighted mean discrepancy score was calculated for each item, for ranking each of the entrepreneurship skills agriculture teachers needed for inservice training. The 20 entrepreneurial skills were then ranked using the weighted mean scores.

\section{RESULTS}

\section{Background characteristics of respondents}

The background characteristics of respondents that participated in the survey were taken and analyzed. These included: region of school, gender, age, academic qualification, subject taught and teaching experience. In summary, in terms of agriculture teachers' demographics, both males and females who participated in the study showed incompetence in imparting entrepreneurial skills to learner with mean values of $(\mathrm{M}=3.31 ; \mathrm{SD}=.75)$ and $(\mathrm{M}=3.21 ; \mathrm{SD}=.89)$ respectively. Both mean values ranged below 3.50. However, males had better levels of competence compared to females. In terms of age groups, the age group between 21 - 30 years had better levels of competence $(\mathrm{M}=3.39$; $\mathrm{SD}=.87)$, followed by the age group between $31-40$ years old $(M=3.38 ; S D=$ $.87)$, then age group $41-50$ years $(M=3.01 ; S D=.69)$ and lastly those above 51 years $(\mathrm{M}=2.99$; $\mathrm{SD}=.63)$. Agriculture teachers from the Lubombo region, however, had higher competence levels $(\mathrm{M}=3.97 ; \mathrm{SD}=.72)$ when compared to those from other regions. These were followed by teachers from the Manzini region $(M=3.13$; $\mathrm{SD}=.72)$, then those who teach in the Shiselweni region $(\mathrm{M}=3.11 ; \mathrm{SD}=.69)$ and lastly those who teach in the Hhohho region $(\mathrm{M}=3.05$; $\mathrm{SD}=.72$ ). The level of education has an impact on competence level of teachers as teachers who have an Msc.in Agriculture Education were more competent $(M=3.53$; $S D=1.06)$ than other teachers with lower educational levels. These were followed by those who have a Bsc.in Agriculture Education $(\mathrm{M}=3.33$; $\mathrm{SD}=.85)$, then those with a Diploma in Agriculture Education $(\mathrm{M}=3.11$; $\mathrm{SD}=.81)$ and last, but not least, those who have Bsc. in Agriculture $(\mathrm{M}=3.05 ; \mathrm{SD}=.61)$. Teachers with a Bsc. in Agriculture are different to those who have a Bsc. In Agricultural Education in that the former did not take educational courses at tertiary and hence lack the professional competences of being teachers, whilst the latter are professional teachers. With regards to the subject taught by teacher at school, teachers who teach pre-vocational agriculture were more competent $(M=4.00 ; S D=.95)$ than teachers who teach modern agriculture $(\mathrm{M}=3.05$; $\mathrm{SD}=.66)$. Lastly, agriculture teachers who have a teaching experience of between $1-5$ years $(M=3.38$; $\mathrm{SD}=.85$ ) are more competent when compared to others, followed by those with 21 years teaching experience and above $(\mathrm{M}=3.30 ; \mathrm{SD}=.90)$ then agriculture teachers with $6-10$ years of teaching experience $(\mathrm{M}=3.28 ; \mathrm{SD}=.83)$ and the rest those with a teaching experience of $16-20$ years $(\mathrm{M}=3.21 ; \mathrm{SD}=.87)$.

\section{Objective 1: Agriculture teachers' perceived importance levels of entrepreneurial skills to impart to learners}

Findings in Table 1 show that all agriculture teachers rated all 20 identified entrepreneurial skills important to teaching high school learners in Eswatini. Highly rated skills of importance include among others the following: teaching learners the basics of how to advertise a product (5.56); teaching learners problem solving skills (5.47); and teaching learners how to develop a product for a specific market (5.40). The least rated entrepreneurial skills include: teaching learners the skill of deciding when to quit (4.94), teaching learners how to become risk takers (4.96) and teaching learners effective negotiation skills (5.00).

\section{Objective 2: Agriculture teachers' competence levels in imparting entrepreneurial skills to learners}

Findings in Table 2 show that respondents were competent in only six (6) entrepreneurial skills which included, among others; teaching learners effective 
Table 1. Perceived importance of entrepreneurial skills for high school learners.

\begin{tabular}{lcc}
\hline Ranked item & M & SD \\
\hline 1. Teaching learners the basics of how to advertise a product & 5.56 & .70 \\
2. Teaching learners problem solving skills & 5.47 & .74 \\
3. Teaching learners how to develop a product for a specific market & 5.40 & .78 \\
4. Teaching learners how to become good decision makers & 5.40 & .94 \\
5. Teaching learners sound financial skills & 5.36 & .85 \\
6. Teaching learners to become innovative & 5.33 & .91 \\
7. Teaching learners how to procure critical resources to start an enterprise & 5.30 & .80 \\
8. Teaching learners the essentials of selling skills & 5.30 & .83 \\
9. Teaching learners how to identify business opportunities & 5.30 & .83 \\
10. Teaching learners effective customer care service skills & 5.27 & .92 \\
11. Teaching learners how to generate business ideas & 5.21 & .91 \\
12. Teaching learners how to develop analytical thinking skills & 5.20 & 1.09 \\
13. Teaching learners effective communication skills & 5.16 & 1.10 \\
14. Teaching learners how to analyse the business environment & 5.12 & 1.05 \\
15. Teaching learners how to easily adapt to changing market conditions & 5.08 & 1.16 \\
16. Teaching learners preliminary costing/pricing skills & 5.04 & .84 \\
17. Teaching learners how to analyse the basics of a contract & 5.02 & 1.05 \\
18. Teaching learners effective negotiation skills & 5.00 & 1.09 \\
19. Teaching learners how to become risk takers & 4.96 & 1.27 \\
20. Teaching learners the skill of deciding when to quit in a business/enterprise & 4.94 & 1.12 \\
Overall mean & 5.22 & 0.94 \\
\hline
\end{tabular}

Table 2. Competence level to impart entrepreneurial skills to learners $(N=227)$.

\begin{tabular}{clcc}
\hline Rank & Item & Mean & Standard deviation \\
\hline 1 & Teaching learners effective communication skills & 3.75 & 1.30 \\
2 & Teaching learners how to become good decision makers & 3.73 & 1.20 \\
3 & Teaching learners the basics of how to advertise a product & 3.66 & 1.30 \\
4 & Teaching learners how to develop analytical thinking skills & 3.63 & 1.04 \\
5 & Teaching learners problem solving skills & 3.62 & 1.13 \\
6 & Teaching learners the essentials of selling skills & 3.55 & 1.26 \\
7 & Teaching learners how to develop a product for a specific market & 3.47 & 1.31 \\
9 & Teaching learners to become innovative & 3.40 & 1.14 \\
10 & Teaching learners how to identify business opportunities & 3.33 & 1.15 \\
11 & Teaching learners how to become risk takers & 3.29 & 1.20 \\
12 & Teaching learners sound financial skills & 3.22 & 1.26 \\
13 & Teaching learners how to generate business ideas & 3.17 & 1.18 \\
14 & Teaching learners how to analyse the business environment & 3.09 & 1.28 \\
15 & Teaching learners how to procure resources to start an enterprise & 3.09 & 1.28 \\
16 & Teaching learners effective customer care service skills & 3.08 & 1.42 \\
17 & Teaching learners preliminary costing/pricing skills & 3.07 & 1.32 \\
18 & Teaching learners how to adapt to changing market condition & 3.04 & 1.20 \\
19 & Teaching learners effective negotiation skills & 2.90 & 1.28 \\
20 & Teaching learners the skill of deciding when to quit in a business & 2.70 & 1.27 \\
21 & Teaching learners how to analyse basics of a contract & 2.42 & 1.28 \\
Overall & mean & 3.26 & 1.24 \\
\hline
\end{tabular}

communication skills (3.75); teaching learners how to become good decision makers (3.73); teaching learners the basics of how to advertise a product (3.66); and teaching learners how to develop analytical thinking skills 
Table 3. Competence level of modern versus pre-vocational agriculture teachers $(N=227)$.

\begin{tabular}{|c|c|c|c|c|c|}
\hline \multirow{2}{*}{ Rank } & \multirow{2}{*}{ Item } & \multicolumn{2}{|c|}{ Modern } & \multicolumn{2}{|c|}{ Pre-vocational } \\
\hline & & Mean & SD & Mean & SD \\
\hline 1 & Teaching learners effective communication skills & 3.59 & .98 & 4.98 & 1.25 \\
\hline 2 & Teaching learners how to become good decision makers & 3.46 & 1.06 & 4.64 & 1.24 \\
\hline 3 & Teaching learners the basics of how to advertise a product & 3.45 & 1.22 & 4.36 & 1.32 \\
\hline 4 & Teaching learners how to develop analytical thinking skills & 3.40 & .92 & 4.40 & 1.06 \\
\hline 5 & Teaching learners problem solving skills & 3.51 & .99 & 4.02 & 1.47 \\
\hline 6 & Teaching learners the essentials of selling skills & 4.02 & 1.44 & 4.02 & 1.44 \\
\hline 7 & Teaching learners how to develop a product for a specific market & 3.24 & 1.20 & 4.24 & 1.40 \\
\hline 8 & Teaching learners to become innovative & 3.19 & 1.06 & 4.18 & 1.10 \\
\hline 9 & Teaching learners how to identify business opportunities & 3.16 & .97 & 3.98 & 1.43 \\
\hline 10 & Teaching learners how to become risk takers & 3.08 & 1.11 & 3.98 & 1.25 \\
\hline 11 & Teaching learners sound financial skills & 3.08 & 1.23 & 3.70 & 1.21 \\
\hline 12 & 12. Teaching learners how to generate business ideas & 2.85 & .98 & 4.30 & 1.16 \\
\hline 13 & 13. Teaching learners how to analyze the business environment & 2.77 & 1.06 & 4.18 & 1.42 \\
\hline 14 & 14. Teaching learners how to procure critical resources to start an enterprise & 2.86 & 1.14 & 3.92 & 1.42 \\
\hline 15 & 15. Teaching learners effective customer care service skills & 2.86 & 1.29 & 3.86 & 1.62 \\
\hline 16 & 16. Teaching learners preliminary costing/pricing skills & 2.84 & 1.20 & 3.88 & 1.39 \\
\hline 17 & 17.Teaching learners how to adapt to changing market conditions & 2.76 & 1.01 & 4.02 & 1.33 \\
\hline 18 & 18. Teaching learners effective negotiation skills & 3.08 & 1.11 & 3.96 & 1.17 \\
\hline 19 & 19. Teaching learners the skill of deciding when to quit in a business & 2.53 & 1.21 & 3.26 & 1.35 \\
\hline 20 & 20.Teaching learners how to analyze basics of a contract & 2.30 & 1.26 & 2.86 & 1.30 \\
\hline \multicolumn{2}{|c|}{ Overall mean } & 33.10 & 1.12 & 4.03 & 1.31 \\
\hline
\end{tabular}

(3.63). Respondents shown to be deficient in 14 skill competence areas which start from item 7 in Table 2, teaching learners how to develop a product for a specific market with 3.47 weighted mean to item 20, teaching them (students) how to analyze the basics of a contract (2.42).

\section{Competence level of modern versus pre-vocational agriculture teachers in entrepreneurial skills}

Findings in Table 3 show that respondents who teach modern agriculture in school showed competency mean scores that ranged from 4.02 to 2.76 with an overall grand mean of 3.10 and those who teach pre-vocational agriculture had competency mean scores ranging from 4.98 to 2.86 with an overall grand mean of 4.03 . Respondents who taught modern agriculture showed competence in six (6) entrepreneurial skills which included, among others; teaching learners effective communication skills (3.59), teaching learners how to become good decision makers (3.46), teaching learners the basics of how to advertise a product (3.45) and teaching them how to develop analytical thinking skills (3.40). Respondents who taught pre-vocational agriculture, on the other hand showed competence in eighteen (18) entrepreneurial skills which included, among others; teaching learners effective communication skills (4.98), teaching learners how to become good decision makers (4.64), teaching learners the basics of how to advertise a product (4.36) and teaching them how to develop analytical thinking skills (4.40). This result indicates a discrepancy among the two groups of teachers in terms of competence levels. Pre-vocational teachers were more competent in imparting entrepreneurial skills to learners whereas modern agriculture teachers were less incompetent.

\section{Objective 3: Agriculture teachers' entrepreneurship skills in-service training needs to transform learners into entrepreneurs}

The Borich's (1980) model was used to identify the inservice training needs of agriculture teachers. The higher the weighted mean discrepancy score (WMDS), above 10 in the study, the greater the in-service training need. The lower the WMDS, which is below 10 in the study, the lower the need for in-service training in that skill. The entrepreneurial skills for training needs by agriculture teachers are provided in Table 4. Entrepreneurial skills with highest WMDS indicative of training need, in rank order included among other teaching learners: how to analyze the basics of a contract (MWDS $=13.05$ ) to teaching learners how to become innovative (MWDS = 10.28). On the other hand, the entrepreneurial skills that teachers rated themselves competent include among others the following: teaching learners' problem solving 
Table 4. Entrepreneurial in-service training needs of high school agriculture teachers.

\begin{tabular}{|c|c|c|c|c|c|c|}
\hline \multirow{2}{*}{ Rank } & \multirow{2}{*}{ MWDS item } & \multicolumn{2}{|c|}{ Importance } & \multicolumn{2}{|c|}{ Competence } & \multirow{2}{*}{ MWDS } \\
\hline & & M & SD & $\mathbf{M}$ & SD & \\
\hline 1. & Teaching learners how to analyse the basics of a contract & 5.02 & 1.05 & 2.42 & 1.28 & 13.05 \\
\hline 2. & Teaching learners how to procure critical resources needed to start an enterprise & 5.30 & .80 & 3.09 & 1.28 & 11.71 \\
\hline 3. & Teaching learners effective customer care service skills & 5.27 & .92 & 3.08 & 1.42 & 11.54 \\
\hline 4. & Teaching learners sound financial skills & 5.36 & .85 & 3.22 & 1.26 & 11.47 \\
\hline 5. & Teaching learners the skill of deciding when to quit in a business/enterprise & 4.94 & 1.12 & 2.70 & 1.27 & 11.07 \\
\hline 6. & Teaching learners how to generate business ideas & 5.21 & .91 & 3.17 & 1.18 & 10.62 \\
\hline 7. & Teaching learners the basics of how to advertise a product & 5.56 & .70 & 3.66 & 1.30 & 10.56 \\
\hline 8. & Teaching learners effective negotiation skills & 5.00 & 1.09 & 2.90 & 1.28 & 10.50 \\
\hline 9. & Teaching learners how to identify business opportunities & 5.30 & .83 & 3.33 & 1.15 & 10.44 \\
\hline 10. & Teaching learners how to analyse the business environment & 5.12 & 1.05 & 3.09 & 1.28 & 10.44 \\
\hline 11. & Teaching learners how to develop a product for a specific market & 5.40 & .78 & 3.47 & 1.31 & 10.42 \\
\hline 12. & Teaching learners how to easily adapt to changing market conditions & 5.08 & 1.16 & 3.04 & 1.20 & 10.36 \\
\hline 13. & Teaching learners to become innovative & 5.33 & .91 & 3.40 & 1.14 & 10.28 \\
\hline 14. & Teaching learners problem solving skills & 5.47 & .74 & 3.62 & 1.13 & 9.96 \\
\hline 15. & Teaching learners preliminary costing/pricing skills & 5.04 & .84 & 3.07 & 1.32 & 9.92 \\
\hline 16. & Teaching learners the essentials of selling skills & 5.30 & .83 & 3.55 & 1.26 & 9.28 \\
\hline 17. & Teaching learners how to become good decision makers & 5.40 & .94 & 3.73 & 1.20 & 9.02 \\
\hline 18. & Teaching learners how to become risk takers & 4.96 & 1.27 & 3.29 & 1.20 & 8.28 \\
\hline 19. & Teaching learners how to develop analytical thinking skills & 5.20 & 1.09 & 3.63 & 1.04 & 8.16 \\
\hline \multirow[t]{2}{*}{20.} & Teaching learners effective communication skills & 5.16 & .92 & 3.75 & 1.30 & 7.28 \\
\hline & Overall mean & 5.22 & & 3.26 & & 10.23 \\
\hline
\end{tabular}

$M=$ Mean, SD = Standard Deviation and MWDS = Mean Weighted Discrepancy Score.

Table 5. Correlation coefficients between teacher competence levels $(\mathrm{Y})$ and the independent variables $(\mathrm{X})$.

\begin{tabular}{lllc}
\hline & Independent variables $(\mathbf{X})$ & Scale of measurement & Correlation coefficients \\
\hline 1 & Perceived ability to impart entrepreneurship & Interval & $.18_{\mathrm{r}}$ \\
2 & Region & Nominal & $.17_{\mathrm{pb}}$ \\
3 & Sex & Nominal & $.06_{\mathrm{pb}}$ \\
4 & Age & Ratio & $-.18_{\mathrm{r}}$ \\
5 & Highest academic qualification & Ordinal & $-.14_{\mathrm{b}}$ \\
6 & Subjects taught & Nominal & $.42_{\mathrm{pb}}$ \\
7 & Teaching experience & Ratio & $-.07 \mathrm{r}$ \\
\hline
\end{tabular}

skills (MWSD $=9.96$ ) to teaching learners effective communication skills (MWSD $=7.28$ )

\section{Objective 4: Describe the relationship between competence levels of agriculture teachers and their background and demographic characteristics}

Table 5 summarizes the results of the relationship between level of competence and selected characteristics. The findings indicated that a positive moderate association $(r=.42)$ exist between competence level and the subject taught by the teacher in school. Correlations further revealed a positive low association between teacher competence level and their perceived ability to impart entrepreneurial skills $(r=0.18)$ and region $(r=0.17)$. However, a positive negligible association between competence level of teacher and sex (.06) exist. The results further revealed a negative negligible association between competence levels of teacher and characteristics: age $(r=-0.18)$, highest academic qualification $(r=-0.14)$ and teaching experience $(r=-$ 0.07).

\section{DISCUSSION}

Agriculture teachers rated all entrepreneurial skills included in the study as important. Findings are in line with Cheung (2008) who also found that teachers and 
students believed in the importance of entrepreneurship education. Lepistö and Ronkko (2013), further agree, stating that the majority of pre-service teachers were amenable to entrepreneurship education. Agriculture teachers also showed some level of competence in just six (6) out of 20 entrepreneurial skills which include: 1) teaching learners effective communication skills, 2) teaching learners how to become good decision makers, 3) teaching learners the basics of how to advertise a product, 4) teaching learners how to develop analytical thinking skills, 5) teaching learners problem-solving skills and 6) teaching learners the essentials of selling skills. This amounts to agriculture teachers' lack of competencies in 14 entrepreneurial skills which might be a serious constraint to optimizing the students to becoming entrepreneurs after leaving the school.

Findings are in concord with Ndwandwe (2013) who found that agriculture teachers had low levels of competence to teach entrepreneurship skills to their students in Eswatini. Agriculture teachers' entrepreneurial skills are obtainable through training and experience; therefore, there could be a strong possibility that agriculture teacher's lack of competence in entrepreneurial skills resulted from inadequate preservice training in entrepreneurship skills. GustafssonPesonen and Remes (2012) states that entrepreneurship education in pre-service teacher training is either absent or insufficient in many countries and findings reveal that the Kingdom of Eswatini is no exception. As a result, with regard to entrepreneurship education, in-service teachers are frequently unprepared in terms of both theoretical knowledge and in-classroom experience. Seikkula-Leino et al. (2012) also affirm that the coverage of entrepreneurship in the curricula implemented in teacher education is not satisfactory.

Findings also revealed, however, that respondents who were incompetent were those who taught modern agriculture as their overall mean rating was 3.10 compared to 4.03 for teachers who taught Pre-vocational agriculture. Curriculum differences have been cited by the Ministry of Education and Training Policy (2012) as the major reason why the competencies of teachers differ in this aspect. The curriculum under the pre-vocational programme in Eswatini includes entrepreneurship as one of the core modules to be taken by all students, whereas teachers teaching modern agriculture cover only the basic concepts of entrepreneurship. The teaching strategies, curriculum objectives, content, learning strategies and assessment objectives of the two subjects are also different, hence the differences in competence levels. It is no wonder again that a moderate relationship (.42) exists between teacher competence levels and subject taught as revealed by the findings of the study.

Nevertheless, findings reveal a need for agriculture teachers' in-service training in entrepreneurship as prevocational teachers constitute a small percentage (13\%) of agriculture teachers in the country. The long list of identified areas for in-service training in entrepreneurial skills needed by Eswatini High School Agriculture Teachers implies that the way teachers are taught or the way the course in entrepreneurship is delivered at tertiary institution may be revisited for further improvements. The fourteen identified areas of in-service training by the agriculture teachers in entrepreneurial skills should also guide curriculum developers in agriculture when reviewing the present secondary school agriculture curriculum. For the learners to be entrepreneurial, they need to be exposed to these specific skills while they are still in school, and teachers have the responsibility to help them develop and practice the skills. If teachers, however, are not adequately competent themselves, the future youth will be deficient in important skills for success in self-employment and entrepreneurial engagement upon high school completion. It is not possible to expect teachers to be engaged in practical activities on a subject about which they do not have any knowledge, skills or experience.

Without entrepreneurial skills, teachers cannot capacitate their learners in schools and the country will continue to have high unemployment rates. Learners get to understand what is expected of them if they are to become entrepreneurs. Thereafter, through their learning by doing, they will develop confidence to apply these skills in the context of setting up their own ventures, enterprises or businesses. Once learners are furnished with such skills, even someone who had never considered self-employment as his/her future career path will now begin to consider it. These findings have created awareness of entrepreneurship gaps that exist in the educational sector and hence efforts should be made to address these so that potential possibilities for employment, including self-employment will be increased, even in light of the dwindling employment opportunities in the public sector.

\section{CONCLUSIONS AND RECOMMENDATIONS}

The study found that agriculture teachers agreed that the 20 identified entrepreneurial skills are important to be taught to learners so that they become entrepreneurs. Agriculture teachers indicated inadequate competence in imparting the fourteen selected entrepreneurial skills to learners. The facts on ground showed that teachers who were teaching Pre-vocational education in school were more competent in imparting entrepreneurial skills to learners than teachers who were teaching Modern agriculture which means that modern agriculture teachers need in-service training, especially on skills where they indicated incompetence. This finding has also created awareness of entrepreneurship gaps that exist in the educational sector which requires strategic efforts to address the gap so that potential possibilities for employment, including self-employment will be realized, 
even in light of the dwindling employment opportunities in the public sector.

The following recommendations may therefore, be made. The institution preparing agriculture teachers, University of Eswatini (UNESWA, Luyengo Campus) should revise the current teacher education programme structure and processes such that all the entrepreneurial skills identified in this study are incorporated in the teacher training programme. It is recommended that the Ministry of Education and Training (MOET), together with curriculum designers find ways to merge the Modern agriculture curriculums with the Pre-Vocational agriculture curriculum to afford all teachers in schools the same opportunities in terms of entrepreneurial skill development so that all learners in the country benefit, not a selected few. In-service training opportunities in entrepreneurship should be organized by MOET and made available and accessible to serving teachers, especially those who did not take the entrepreneurship course at tertiary institution. The National Curriculum Centre could be guided by the study when reviewing the present secondary school agriculture curriculum and on identifying entrepreneurial skills to be included in the agriculture curriculum.

\section{REFERENCES}

Abiogu GC (2011). Entrepreneurship education: A veritable means of reconstructing tertiary institutions in Nigeria. The $29^{\text {th }}$ Annual Conference of Philosophy of Education Association of Nigeria (PEAN), Lagos State University, Ojo - Lagos State.

Ahmad NH (2007). A cross cultural study of entrepreneurial competencies and entrepreneurial success in SMEs in Australia and Malaysia (Doctoral dissertation).

Akyürek C, Şahin Ç (2013). Evaluation of elementary teachers' entrepreneurship skills. Ekev Akademi Dergisi, 17(57):51- 68.

Bandura A (1986). Social foundation of thought and action. Englewood Cliffs, Prentice-Hall, New Jersey.

Borich GD (1980). A needs assessment model for conducting follow-up studies. J. Teach. Educ. 3(3):39-42.

Bygrave WD (2004). The entrepreneurial process. In W. D. Bygrave \& A. Zacharakis (Eds.). The portable MBA in entrepreneurship. Hoboken, NJ: John Wiley \& Sons.

Cheung CK (2008). Practicing entrepreneurship education for secondary pupils through the operation New Year stall in Hong Kong. Asia-Pac. Educ. Res. 17(1):15- 31.

Davis JA (1971). Elementary Survey Analysis. Prentice Hall: New Jersey

European Commission (2004). Helping to create an entrepreneurial culture: A guide on good practices in promoting entrepreneurial attitudes and skills through education. Unit B.1: Entrepreneurship (SC27 3/4) Directorate-General for Enterprise, B-1049 Brussels.

Garcia-Rodriguez FJ, Gil-Soto E, Ruiz-Rosa I, Sene PM (2017). Entrepreneurship education in Sub-Saharan Africa: Results of a case study in Senegal. J. Entrep. Educ. 20(2):1-15.

Gardner LL (2013). Teaching teachers about supply chain management to influence students' career and education choices. Decision Sci. J. Innov. Educ. 11(2):185-192. doi:10.1111/j.15404609.2013.00372.x.

Ghina A, Simatupang TM, Gustomo A (2017). The relevancy of graduates' competencies to the effectiveness of entrepreneurship education: A case study at SBM ITB-Indonesia. J. Entrep. Educ. 20(1):12-35

Gustafsson-Pesonen A, Remes L (2012). Evaluation of entrepreneurial development coaching: Changing the Teachers' thinking and action on entrepreneurship. Annals of Innovation \& Entrepreneurship, 3. doi:10.3402/aie.v3i0.17211.

Hannula H (2011). Entrepreneurship education in the strategies and curricula of finish vocational teacher education. Contemporary Views on Business Developing Business Excellence.

Haftendorn K, Salzano C (2003). In Facilitating Youth Entrepreneurship, Part I, ILO- SEED Working Paper. 59, 40.

Henry C, Hill F, Leitch C (2005). Entrepreneurship education and training: can entrepreneurship be taught? Part I. Education and Training. 47(2):98-111.

Henry C, McGowan P (2016). Embedding entrepreneurship in higher education institutions: Reconceptualizing entrepreneurship education. The All Ireland Journal of Teaching and Learning in Higher Education. 8(1):2741-2747

Kapu H (2001). The life of Entrepreneurial Managers and Her Life Values. Marmara University, SBE, Unpublished Ph.D. Thesis.

Khumalo T (2010). Developing a Strategy for Urban Youth Employment in Swaziland, UNISWA (December), Special issue sponsored by the Organization for Social Science Research in Eastern and Southern Africa (OSSREA). Res. J. 26(26):99-113.

Malach J, Kristova K (2017). The impact of school education and family environment on pupils' entrepreneurial spirit and attitude to entrepreneurship. The New Educ. Rev. 49(3):101-114.

Ministry of Education (2012). National Education Policy Statement. Mbabane, Swaziland.

Nabi G, Linan F, Fayolle A, Krueger N, Walmsley A (2017). The impact of entrepreneurship education in higher education: A systematic review and research agenda. Acad. Manage. Learn. Educ. 16(2):277-299.

Ndwandwe S (2013). Competence levels of High School Agriculture teachers in Swaziland. Unpublished Master's Thesis. University of Swaziland. Luyengo. Swaziland.

Layfield KD, Dobbins TR (2002). In-service needs and perceived competencies of South Carolina agricultural teachers. J. Agric. educ. 47(4):46-55.

Lepistö J, Ronkko ML (2013). Teacher students as future entrepreneurship educators and learning facilitators. Educ. Train. 55(7):641-653. doi:10.1108/ET-05-2012-0055.

Ministry of Education (2012). National Education Policy Statement. Mbabane, Swaziland.

Ndedi AA (2009). Entrepreneurship Training and Job Creation in South Africa: Are Tertiary Institutions Filling the Gap? J. Contemp. Manage. 6:463-470. www.ahero.uwc.ac.za. Retrieved on 22 ${ }^{\text {nd }}$ July 2015.

OECD (2009). Evaluation of programmes concerning education for entrepreneurship. Report by the OECD Working Party on SMEs and Entrepreneurship, OECD.

Papagiannis GD (2018). Entrepreneurship education programs: The contribution of courses, seminars and competitions to entrepreneurial activity decision and to entrepreneurial spirit and mindset of young people in Greece. J. Entrep. Educ. 21(1):1-21.

Pham D (2018). Contemporary issues in entrepreneurship research volume 7: Entrepreneurship education: New perspectives on research, policy \& practice. Int. J. Entrep. Behav. Res. 24(1):317-319.

Potishuk V, Kratzer J (2017). Factors affecting entrepreneurial intentions and entrepreneurial attitudes in higher education. $\mathrm{J}$. Entrep. Educ. 20(1):36-55.

Seikkula-Leino J, Ruskovaara E, Hannula H, Saarivirta T (2012). Facing the changing demands of Europe: Integrating entrepreneurship education in Finnish teacher training curricula. Eur. Educ. Res. J. 11(3):382-399. doi:10.2304/eerj.2012.11.3.382.

Simiyu J (2010). Entrepreneurship Education as a Tool to Support SelfEmployment in Kenya. UNESCO-UNEVOC, International centre for Technical and Vocational Education and Training, 2. www.unevoc.unesco.org. Retrieved on $29^{\text {th }}$ May 2015.

United Nations Report (2013). Opportunities and Constraints to Youth Entrepreneurship, Mbabane, Swaziland.

University of Swaziland (2010). Calendar 2010/2011. Kwaluseni, Swaziland.

Waters RG, Haskell LJ (1989). Identifying staff development needs of

Cooperative Extension faculty using a modified Borich needs assessment model. J. Agric. Educ. 30(2):26-32.

Zhang Y, Duysters G, Cloodt M (2014). The role of entrepreneurship 
education as a predictor of university students' entrepreneurial intention. Int. Entrep. Manage. J. 10(3):623-641. 